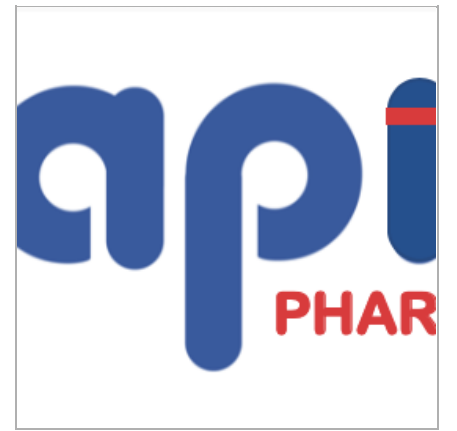

AUG 13, 2020

\title{
(3) API Pharma Next Gen Antibody Test
}

vincent.degennaro ${ }^{1}$

${ }^{1} \mathrm{API}$ Pharma LLC

Coronavirus Method Development Community

API Pharma LLC 1 more workspace $\downarrow$

vincent.degennaro

\section{open $\boldsymbol{\partial}$ ACCESS}

DOI:

dx.doi.org/10.17504/protocol s.io.bjqqkmvw

Document Citation: vincent. degennaro 2020. API Pharma Next Gen Antibody Test. protocols.io

https://dx.doi.org/10.17504/p rotocols. io. bjqqkmvw

License: This is an open access document distributed under the terms of the Creative Commons Attribution License, which permits unrestricted use, distribution, and reproduction in any medium, provided the original author and source are credited

Created: Aug 13, 2020

Last Modified: Aug 13, 2020

DOCUMENT integer ID:

40432

Manufacturer Information

\section{Kit Name: API Pharma Next Gen SARS CoV-2 IgM/lgG Antibody Test \\ Kit Manufacturer:Division 5 Labs \\ Importer of Record: API Pharma USA LLC}

\section{Environmental Storage}

- Store as packaged in the sealed pouch at the temperature $\left(4-30^{\circ} \mathrm{C}\right)$.Avoid hot and sunshine, dry place, valid for 12 months.DO NOT FREEZE.Some protective measures should be taken in hot summer and cold winter to avoid high temperatures or freezethaw.

- Do not open the inner packaging until ready, it must be used in 1 hour if opened

- Humidity: $<=60 \%$, Temp: $20 \mathrm{C}-30^{\circ} \mathrm{C}$ 
- Please use immediately when humidity is $>60 \%$.

\section{Specimen}

The reagent can be used for the serum, plasm and whole blood samples.A serum plasma whole blood sample must be collected in a clean and dry container.EDTA, sodium citrate, heparin can be used as anticoagulants. in plasma/whole blood samples.Detect immediately after collecting blood.

Serum and plasma samples may be stored at $2-8^{\circ} \mathrm{C}$ for 7 days prior to assay. If testing is delayed more than 7 days, the sample should be frozen $\left(-20^{\circ} \mathrm{C}\right.$ or colder). Repeat freeze and thaw for no more than 3 times.

Whole blood samples with anticoagulant can be stored at $2-8^{\circ} \mathrm{C}$ for 3 days and should not be frozen. Whole blood samples without anticoagulant should be used immediately (if the sample has agglutination, it can be detected as serum).

\section{Quality Control}

A procedural control is included in the test. A colored line appearing in the control region (C) considered an internal procedural control. It confirms sufficient specimen volume, adequate membrane wicking and correct procedural technique.

\section{.Intended Use}

The kit is used to detect IgG and IgM antibodies to severed acute respiratory syndrome coronavirus 2 (SARS-CoV-2) the SARS-CoV2 virus in serum, plasma or whole blood sample qualitatively.It is to be used as an aid in the diagnosis of coronavirus infection disease (COVID-19), which is caused by SARS-CoV-2

\section{Test Principle}

This kit is an immunochromatographic assay, using capture method for quantitative detection of severe acute respiratory syndrome coronavirus 2(SARS CoV-2) IgG/IgM antibody in human serum plasma and whole blood sample. When the sample contains the SRS CoV-2 IgM antibody, it forms a complex with the gold label antigen (SARS-CoV-2 recombinant antigen. The complex moves forward under the action of chromatography and combines with the coated antibody (Mouse anti-human IgM monoclonal antibody) at the T2 line to form a complex and develop color (T2line), which indicates positive result. When the sample does not contain the SARS-CoV-2 IgM antibody, no complex can be formed at the T2 line and no red band appears which indicates a negative test.

When the sample contains the SARS CoV-2 IgG antibody, it forms a complex with the gold label antigen (SARS-CoV-2 recombinant antigen. The complex moves forward under the action of chromatography and combines with the coated antibody (Mouse antihuman IgG monoclonal antibody) at the $\mathrm{T} 1$ line to form a complex and develop color ( $\mathrm{T} 1$ line), which indicates positive result. When the sample does not contain the SARS-CoV-2 IgG antibody, no complex can be formed at the T1 line and no red band appears which indicates a negative test.

Regardless of whether the SARS-CoV-2 IgM and/or IgG antibody is contained in the sample, the gold label quality control antibody (Biotinylated BSA) will bind with the coated antibody at the $\mathrm{C}$ line to form a complex and develop color (C Line). 


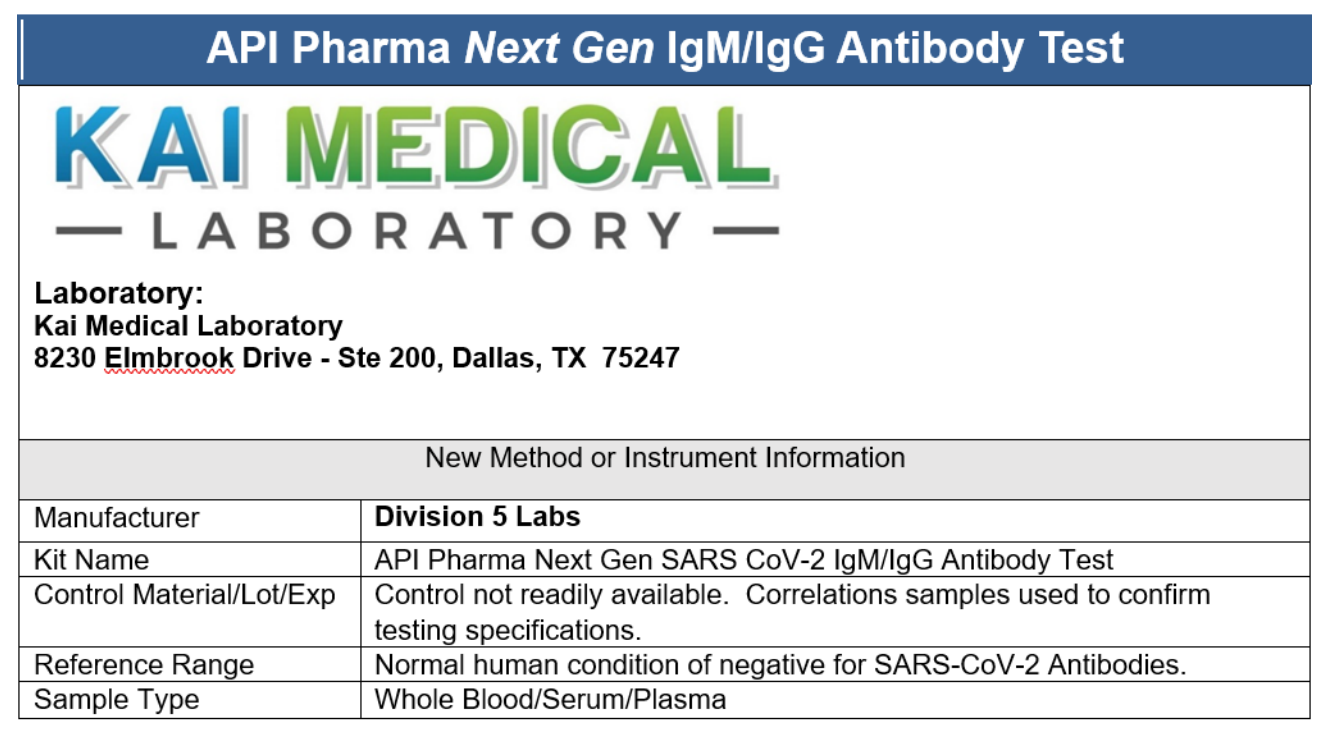

\begin{tabular}{|c|c|c|c|}
\hline Detail & Date Performed & Detail & Acceptable? \\
\hline $\begin{array}{l}\text { Accuracy/ Correlation } \\
\text { Qualitative }\end{array}$ & 7.3 .2020 & $\begin{array}{l}10 \text { out of } 10 \text { negative } \mathrm{lgG} / \mathrm{gM} \text { samples correlated with } \\
\text { expected results. } \\
\begin{array}{l}10 \text { out of } 10 \text { positive IgG samples correlated with } \\
\text { expected results. }\end{array} \\
\begin{array}{l}10 \text { out of } 10 \text { positive IgM samples correlated with } \\
\text { expected results. }\end{array}\end{array}$ & YES \\
\hline $\begin{array}{l}\text { Precision } 2 \text { levels } \\
N=20 \\
\text { JEa } 20 \%\end{array}$ & 7.3 .2020 & $\begin{array}{l}\text { Control Samples not readily available. Patient testing } \\
\text { used to perform positive and negative replicates. } \\
\text { Testing: Neg/Ros_10 replicates each }\end{array}$ & YES \\
\hline Selectivity/Specificity & 7.3 .2020 & $\begin{array}{l}\text { Positive dilution tests was performed at } 1: 3,1: 5,1: 10 \\
\text { All dilutions demonstrated visible positive immunoglobulin } \\
\text { bands. } \\
\text { Hemolysis interference testing performed on positive and } \\
\text { negative samples. No interference demonstrated. }\end{array}$ & YES \\
\hline Reference Range & 7.3 .2020 & $\begin{array}{l}\text { Negative result is supported by normal human biological } \\
\text { condition. }\end{array}$ & YES \\
\hline Sample Stability & NA & See package inserts & NA \\
\hline Comments: & & & \\
\hline
\end{tabular}

\section{Sensitivity and Specificity}

All samples were gathered from patients May 4 to July $2^{\text {nd }}$. Samples that were stored more than three days were frozen. Dates of symptom onset were written by clinical site. Since many patients were asymptomatic, it was not possible to determine date of onset. All patients had a nasopharyngeal swab taken at the same time as the blood sample. PCR results for each patient are listed below.

Procedure:

1. Removed the test device from the sealed pouch.

2. Added $40-50 \mu \mathrm{l}$ of serum or plasma or $80-100 \mu$ l of whole blood vertically into the sample well.

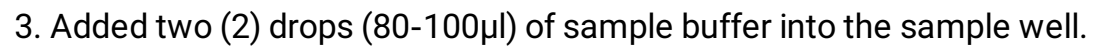

4. Observed the test results immediately within 15 20 minutes, the result is invalid over 20 minutes.

Note: Any color change around the region of a line, even if faint or indistinct, was considered a positive result. 
SARS-CoV-2 IgM/lgG Ab

\begin{tabular}{|c|c|c|c|c|c|}
\hline & $\begin{array}{l}\text { API Test Result Compared } \\
\text { to PCR }\end{array}$ & & & & \\
\hline $\begin{array}{l}\text { Days from Symptom onset } \\
\text { to Blood Collection }\end{array}$ & Number of samples & $\begin{array}{l}\text { 2019- } \\
\text { nCoV } \\
\text { RT } \\
\text { PCR } \\
\text { Result }\end{array}$ & $\begin{array}{l}\text { IgM } \\
(+)\end{array}$ & $\begin{array}{l}\lg G \\
(+)\end{array}$ & $\begin{array}{l}\text { IgM } \\
(+) \\
\text { and/o } \\
\text { r lgG } \\
(+) \\
(+)\end{array}$ \\
\hline $1-5$ days & 14 & Pos & 14 & 14 & 14 \\
\hline $6-10$ days & 16 & Pos & 13 & 16 & 16 \\
\hline $11-15$ days & 0 & & & & \\
\hline $16-20$ days & 0 & & & & \\
\hline$>20$ days & 0 & & & & \\
\hline Asymptomatic & 25 & Pos & 23 & 25 & 25 \\
\hline Total & 55 & Pos & 50 & 55 & 55 \\
\hline
\end{tabular}

SARS-CoV-2 IgM Ab

\begin{tabular}{|l|l|l|l|}
\hline $\begin{array}{l}\text { SARS-CoV-2 IgM Ab } \\
\text { Rapid Test }\end{array}$ & PCR Test & Total & \\
\hline Positive & Negative & & \\
\hline Positive & 50 & 0 & 50 \\
\hline Negative & 5 & 85 & 90 \\
\hline Total & 55 & 85 & 140 \\
\hline
\end{tabular}

Analysis of coincidence rate of SARS-CoV-2 IgM Ab rapid test and PCR Test in blood samples.

Positive Percent Agreement $=50 /(50+5) \times 100 \%=90.9 \%$

Negative Percent Agreement $=85 /(85+0) \times 100 \%=100 \%$

\section{SARS-CoV-2 IgG Ab}

\begin{tabular}{|l|l|l|}
\hline $\begin{array}{l}\text { SARS-CoV-2 IgG Ab } \\
\text { Rapid Test }\end{array}$ & PCR Test & Total
\end{tabular}




\begin{tabular}{|l|l|l|l|}
\hline Positive & Negative & & \\
\hline Positive & 55 & 0 & 55 \\
\hline Negative & 0 & 85 & 85 \\
\hline Total & 55 & 85 & 140 \\
\hline
\end{tabular}

Analysis of coincidence rate of SARS-CoV-2 IgG Ab rapid test and PCR Test in blood samples.

Positive Percent Agreement $=50 /(55+0) \times 100 \%=100 \%$

Negative Percent Agreement $=85 /(85+0) \times 100 \%=100 \%$

\section{HIV + Samples}

Ten asymptomatic HIV+ patients with no known exposure to COVID19 were recruited through Kai Medical in Dallas Texas. Patient HIV status was confirmed using standard of care HIV testing. Patients were given API Pharma Rapidtesting and results were confirmed by PCR. $100 \%$ of patients tested negative for COVID19 by API Pharma Rapid testing.

\begin{tabular}{|l|l|l|l|}
\hline $\begin{array}{l}\text { Patient } \\
\text { Number }\end{array}$ & $\begin{array}{l}\text { HIV } \\
\text { test result }\end{array}$ & $\begin{array}{l}\text { API } \\
\text { Pharma Rapid } \\
\text { Test Result }\end{array}$ & $\begin{array}{l}\text { PCR } \\
\text { Test Result }\end{array}$ \\
\hline $\begin{array}{l}\text { Patient } \\
1\end{array}$ & Pos & Neg & Neg \\
\hline $\begin{array}{l}\text { Patient } \\
2\end{array}$ & Pos & Neg & Neg \\
\hline $\begin{array}{l}\text { Patient } \\
3\end{array}$ & Pos & Neg & Neg \\
\hline $\begin{array}{l}\text { Patient } \\
4\end{array}$ & Pos & Neg & Neg \\
\hline $\begin{array}{l}\text { Patient } \\
5\end{array}$ & Pos & Neg & Neg \\
\hline $\begin{array}{l}\text { Patient } \\
6\end{array}$ & Pos & Neg & Neg \\
\hline $\begin{array}{l}\text { Patient } \\
7\end{array}$ & Pos & Neg & Neg \\
\hline $\begin{array}{l}\text { Patient } \\
8\end{array}$ & Pos & Neg & Neg \\
\hline $\begin{array}{l}\text { Patient } \\
9\end{array}$ & Pos & Neg & Neg \\
\hline $\begin{array}{l}\text { Patient } \\
10\end{array}$ & Pos & Neg & Neg \\
\hline
\end{tabular}


This validation study has been reviewed and the performance of the Division 5 LabsAPI Pharma Next Gen IgM/lgG Antibody Test method is considered acceptable for patient testing of SARS CoV-2 IgG/lgM Antibodies.

\begin{tabular}{|l|l|}
\hline $\begin{array}{l}\text { Coordinating Testing: } \\
\text { Michael Haines }\end{array}$ & Date: 7.20 .2020 \\
\hline $\begin{array}{l}\text { Technical } \\
\text { Supervisor: Kathleen Braniff, } \\
\text { MSA, } \\
\text { MT(ASCP) }\end{array}$ & $\begin{array}{l}\text { Date: } \\
7.20 .2020\end{array}$ \\
\hline $\begin{array}{l}\text { Laboratory } \\
\text { Director: }\end{array}$ & Date: \\
\hline
\end{tabular}


